\title{
Effect of Powdery Scab Root Galls on Yield of Potato
}

\author{
Dennis A. Johnson and Thomas F. Cummings, Department of Plant Pathology, Washington State University, Pullman, WA 99163-6430
}

\begin{abstract}
Johnson, D. A., and Cummings, T. F. 2015. Effect of powdery scab root galls on yield of potato. Plant Dis. 99:1396-1403.

Powdery scab of potato, caused by Spongospora subterranea f. sp. subterranea, has increased in incidence since 1981 to become a major concern for potato production in the Columbia Basin of south-central Washington and north-central Oregon. Disease symptoms consist of pustules on the tuber surface and wart-like galls on roots, stolons, and tubers. In the current study, the effect of powdery scab root galls on potato yield was quantified by comparing yields of cultivars susceptible and resistant to root galling grown on soil naturally infested and noninfested with the powdery scab pathogen. Potato tuber yields for the three yield components of yield per plant, number of tubers, and weight of tubers were not negatively affected by powdery scab

galls on roots of Umatilla Russet and Shepody, as indicated by yield ratios $\geq 1.0$ in 3 of 4 years, and also by regression analyses in all 3 years. Regression lines with a nonsignificant slope or slopes that significantly increased with gall index also indicated that root galls did not negatively affect yield. Mean tuber weight increased as gall index increased for Umatilla Russet in 2 of 3 years. Consequently, control tactics directed solely at reducing powdery scab galls on roots are not justified economically under conditions encountered in the Columbia Basin of Washington and Oregon states. Effort has been made to develop resistant cultivars and search for soil applied chemicals to reduce root galls.
\end{abstract}

Powdery scab of potato, caused by the soilborne, plant endoparasitic slime mold, Spongospora subterranea f. sp. subterranea J. A. Toml. (subsequently referred to as S. subterranea), is a major concern for potato (Solanum tuberosum subsp. tuberosum) production in the Columbia Basin of south-central Washington and northcentral Oregon. Occurrence of powdery scab in the Columbia Basin before 1981 was limited and sporadic, whereas now the disease occurs at high severities in many fields throughout the region (Johnson and Miliczky 1993; Nitzan et al. 2010). The pathogen is present in many potato-production regions worldwide (Gans et al. 1987; Gilchrist et al. 2011; Harrison et al. 1997; Merz 2008; Walker 1950). Infected seed tubers and contaminated soils are means of disseminating the pathogen, and Spongospora subterranea also transmits the Potato mop top virus that causes potato mop top (Jones and Harrison 1969).

Powdery scab is a polycyclic disease (Powelson and Rowe 2008). The disease cycle initiates by the release of a single primary zoospore from sporosori (resting spores) (Harrison et al. 1997; Merz 2008). The primary zoospores infect potato root hairs early in the growing season in the Columbia Basin, when soils are relatively cool (Johnson and Miliczky 1993; Ramsey 1918). Rain and irrigation water supplies the free water needed for zoospore dissemination and infection (Adams et al. 1987). Zoospores are motile and bear two unequal, anterior whiplash type flagella (Alexopoulos 1962). A multinucleated plasmodium develops in the host following infection, which then gives rise to zoosporangia. The cleaving of zoosporangia produces either secondary zoospores or new sporosori. The secondary zoospores infect roots, stolons, and tubers. Zoospores released from pustules on tubers, galls on roots and stolons, or sporosori may reinfect the host and repeat the life cycle as long as favored by the environment. Favorable soil temperatures for infection range from 11 to $18^{\circ} \mathrm{C}$ (Harrison et al. 1997). Sporosori can remain viable on root tissue or freely in soil for many years (Kole 1954).

S. subterranea, which is an obligate pathogen, can complete its life cycle primarily by infecting and forming resting spores on tubers and roots of potato. However, roots of a few closely related weeds and crop plants such as black nightshade (Solanum nigrum), hairy nightshade (S. sarrachoides), jimsonweed (Datura stramonium), pepper,

Accepted for publication 7 March 2015.

http://dx.doi.org/10.1094/PDIS-11-14-1170-RE

(C) 2015 The American Phytopathological Society and tomato may serve as alternative hosts (Nitzan et al. 2009a; Qu and Christ 2006; Walker 1950).

Powdery scab symptoms are confined to belowground plant organs, and generally do not become visible for three or more weeks after infection (Bhattacharyya and Raj 1981; Johnson and Miliczky 1993). Infection results in abnormal enlargement or hypertrophy of cells (Walker 1950). Infected roots and stolons develop wart-like galls, which are white at first and turn brown to black as they mature. Galls vary in size up to that of a pea. Disease symptoms on young tubers consist of small, gray, elevated pustules on the tuber surface. Pustules later dry and break open, leaving circular to oval, small, scabby pits. The pits contain a yellow-brown powder that consists of a mass of clustered sporosori (Harrison et al. 1997; Melhus et al. 1916).

Pustules on tubers can be entry points for infection by Phytophthora erythroseptica Pethybr., the cause of pink rot, and $P$. infestans (Mont.) de Bary, the cause of late blight (D. A. Johnson, unpublished data). Pustules on tubers additionally break the preventive chemical barrier to $P$. infestans and $P$. erythroseptica formed at the tuber periderm from systemic fungicides such as metalaxyl (D. A. Johnson, unpublished data). Tubers with powdery scab lesions have had increased incidences of late blight (Schultz 1952), pink rot (Diriwachter and Parbery 1991), dry rot (caused by Fusarium solani var. coeruleum (Lib. ex Sacc.) C. Booth) (Foister et al. 1952), and black dot (caused by Colletotrichum coccodes (Wallr.) S. Huges) (Wade 1949).

Most commercial potato cultivars develop root galls at various severities when inoculum levels and environment favor infection (Nitzan et al. 2010). Tubers of white- and red-skinned potato cultivars are susceptible, and those of russet-skinned cultivars are partially resistant and are usually not damaged significantly (Nitzan et al. 2010). Resistance to the root and tuber phases of the disease appear to be inherited independently (Gans et al. 1987; Merz et al. 2004). Elevated physiological levels of LOX protein in the skin region are related to tuber russet skin and powdery scab resistance of russet cultivars, and physiological levels of the protein appear to be a potentially useful marker for selecting powdery scab resistance in potato tubers (Perla et al. 2014).

Potato seed tubers with powdery scab pustules can be rejected for sale, causing a large financial loss for individual potato seed producers (Merz 2008). Tubers with powdery scab symptoms intended for consumption are unsightly and are often rejected for fresh markets (Falloon et al. 2004). The processing industry has not been able to peel scabby tubers and such tubers may be rejected for processing (D. A. Johnson, unpublished data). 
Plants with a severe level of root galls have been reported to wilt and die but this is seldom observed (Christ 2001). Powdery scab root galling was stated to cause yield losses of up to 5 to 12 metric tons/ha in Washington State (Brown et al. 2007); however, a noninfected control treatment for comparison with infected plants and the elimination of other soilborne pathogens such as Verticillium dahliae (Kleb.) and C. coccodes were not done in that study to make a reliable loss estimation. In a controlled experiment in Colombia, reductions of $23 \%$ for plant length, $32 \%$ for foliar dry weight, and $30 \%$ for tuber weight were attributed to powdery scab root galling for 'Diacol Capiro', which is a member of the andigena subspecies of Solanum tuberosum (Gilchrist et al. 2011). Infested and noninfested soil in containers was used in that study in Colombia but methods were not described for how the soil was infested and whether other pathogens were successfully excluded (Gilchrist et al. 2011). Tuber yield of potato was also reduced in a shadehouse environment when soil was infested with Spongospora subterranea inoculum prepared by peeling the periderm from powdery-scab-infected tubers grown in the field (Shah et al. 2012).

A few cultivars are available with resistance to root galling (Nitzan et al. 2008, 2010). Other than resistance and avoiding infested fields, satisfactory management tactics are not currently available for reducing root galls on commercial cultivars and limiting tuber pustules on white- and red-skinned potato cultivars (Falloon 2008; Houser and Davidson 2010; Qu and Christ 2006). Delaying planting to reduce the time period during which potato plants are grown in diseasefavorable cool soil temperatures may reduce severity of powdery scab due to disease escape (Christ and Weidner 1988; Johnson and Miliczky 1993) but early markets and maximum yields may be sacrificed with this practice.

The effect of root galls on yield of potato (Solanum tuberosum spp. tuberosum) under commercial production in the Columbia Basin of Washington State has not been quantified satisfactorily. The effect of root galls on yield should be quantified to established action and economic thresholds, and determine whether control tactics are applicable for this phase of the disease (Rowe and Powelson 2008). Methods available to determine yield reduction caused by the obligate pathogen Spongospora subterranea are limited because neither chemical controls (Houser and Davidson 2010) nor resistant isogenic lines are available to provide a comparison between diseased and nondiseased plants (James 1974). Comparing yields of plants grown in infested and noninfested soil in containers is risky because soil inoculated with root galls or tuber periderm produced in the field may be infected or infested with other soilborne pathogens such as $V$. dahliae and C. coccodes (D. A. Johnson, unpublished data), thereby inadvertently contaminating the test soil and confounding the yield loss estimate. This study tested the hypothesis that infection of potato roots by $S$. subterranea under commercial production practices in the Columbia Basin results in yield reduction due to impairment of the root system. The purpose of this research was to determine quantitatively this effect on yield of potato (Solanum tuberosum spp. tuberosum). Yield from cultivars resistant and susceptible to root galling in naturally infested and noninfested field soil were compared to measure the effect of powdery scab root galls on yield.

\section{Materials and Methods}

General. Field trials were conducted in soil naturally infested and noninfested with Spongospora subterranea f. sp. subterranea in 2007, 2008, 2010, 2011, and 2012. The infested soils were in commercial fields near Warden, WA, and the noninfested soil was at the Washington State University Experiment Station near Othello. Soil type at Warden was a Timmerman coarse sandy loam in 2007, and a Quincy fine sand in 2008, 2010, 2011, and 2012; whereas, at Othello the soil type was a Shano silt loam for all 5 years. Different fields or plot areas were used each year. Preplant and in-season applications of fertilizers, herbicides, insecticides, and overhead irrigation were used according to standard commercial potato cultural practices for the Columbia Basin (Gudmestad 2008). The fields near Warden were approximately 27 to $31 \mathrm{~km}$ from the plots at the Experiment Station near Othello.
Cultivars used were 'Shepody', 'Umatilla Russet', 'Summit Russet', and 'Mesa Russet'. Shepody is very susceptible, Umatilla Russet is susceptible, and Summit Russet and Mesa Russet are resistant to powdery scab root gall development (Nitzan et al. 2008). A resistant and at least one susceptible cultivar were planted at each location each year. Cultivars each year were planted from certified seed tubers cut to 70-g seed pieces. Data recorded for each cultivar at each location and year were root gall index, incidence of plants with root galls, and the yield components of total yield, number of tubers, and mean tuber weight, as described below.

Root systems of three plants per plot were dug carefully by hand with a forked spade to expose, but not to dislodge, root galls. Roots of plants adjacent to the plots were sampled beginning in early August to determine the optimum time to assess the number of root galls. Plant roots were dug when galls were mature but not beginning to dry and excise. Soil was gently removed from the sampled root systems, and the numbers of galls per root system were counted and placed in one of six gall index categories, as detailed below. Actual number of galls per root system was counted for one plant per plot of each cultivar as a standard for assessment accuracy for the two additional plants sampled per plot. In 2012, galls on sampled root systems were assessed, and then the same plants were counted separately for galls to determine a quantitative association for each cultivar between the gall index and actual number of plant galls. Gall index categories were as follows: $0=0$ gall, $1=1$ to 25 galls $/$ plant, $2=26$ to 50 galls $/$ plant, $3=51$ to 100 galls $/$ plant, $4=$ 101 to 150 galls/plant, and $5>151$ galls/plant (Nitzan et al. 2008).

Yield ratios were used to evaluate the effect of powdery scab on a yield component for each cultivar between infested and noninfested fields. Yield ratios were derived from the following formula: a yield component of a diseased plot (infested soil)/mean yield component of plots from the nondiseased field (noninfested soil). A yield ratio $\geq 1.00$ for a cultivar indicated that powdery scab galls had a limited negative effect on yield of that cultivar.

The experimental design in 2010 through 2012 was changed from that used in 2007 and 2008 to increase the number of replications and not substantially increase the amount of tubers harvested by hand. Also, in 2010 through 2012, plants sampled for yield components were 0.3 to $0.9 \mathrm{~m}$ away from those plants assessed for number of galls; whereas, in 2007 and 2008, the assessed plants were random along the center row of the 4.6-m length of plot in which plants were also harvested for yield.

Trials in 2007 and 2008. Shepody, Umatilla Russet, and Summit Russet were planted in plots near Warden and Othello in each of 2007 and 2008. Each plot of each cultivar was three rows wide and $4.6 \mathrm{~m}$ long. Distance between rows was $0.86 \mathrm{~m}$. Each row was planted with 18 seed pieces, each piece spaced $25 \mathrm{~cm}$ apart within a row. Cultivars were arranged in a randomized complete block design (RCB), with six replicates at each location; however, some plots were destroyed by cultivation error, thus reducing the number of replications for some cultivars (Table 1 ).

Number of galls per plant was assessed on three plants selected from the center row of each plot. All tubers were harvested, counted, and weighed from the center row of each plot. In 2007, plots were planted on 27 April at Warden and 12 April at Othello. Vines were killed 131 days after planting (DAP), and tubers were harvested on 19 September at both locations. At both locations in 2008, plots were planted on 2 April, vines were killed at 162 DAP, and tubers were harvested and assessed for galls on 24 September.

Trials in 2010 through 2012. Umatilla Russet and Mesa Russet were planted in 2010, whereas Shepody, Umatilla Russet, and Mesa Russet were planted in each of 2011 and 2012 in plots near Warden and Othello. Cultivar plots were single rows, each $1.83 \mathrm{~m}$ long, and were planted with six seed pieces spaced $30 \mathrm{~cm}$ apart within the rows. Rows were spaced $0.86 \mathrm{~m}$ apart. Cultivars were arranged in an RCB design with 10 replicates. Cultivars within a block were arranged and randomized laterally, and replicates were arranged end to end with $0.9 \mathrm{~m}$ of spacing between adjacent replicates. The trial was bordered with a row of 'Alturas' in each of the 3 years. 
Number of galls per plant was assessed on three contiguous plants per plot. Tubers were harvested, counted, and weighed from the other three contiguous plants of the six-plant plots. The plots at Warden and Othello were planted, rated for galls, and harvested on the same day for a given year. Plots were planted on 9 April 2010, 8 April 2011, and 19 April 2012. Three contiguous plants per plot were harvested destructively, and root systems were rated for galls on $24 \mathrm{Au}-$ gust 2010 (137 DAP), 16 August 2011 (129 DAP), and 15 August 2012 (118 DAP). The remaining three plants per plot were harvested for determination of yield components on 17 September 2010 (161 DAP), 16 September 2011 (160 DAP), and 14 September 2012 (149 DAP).

Data analysis. Yield measurements and gall assessments from individual plants were considered subsamples, the mean of which was calculated for each experimental unit (plot). Data for gall index and the three yield components for each location and year were dependent variables analyzed separately by one-way analysis of variance (ANOVA) using an RCB design. The independent variables were block (random) and cultivar (fixed). Least-square means tests for comparisons among cultivars for each location and year were considered significant at $P=0.05$ when the ANOVA $F$ test was significant $(P<0.05)$. Data for yield ratios (dependent variables) for each cultivar (fixed, independent variable) and for each year were analyzed by one-way ANOVA. Significance among cultivars was determined from least-square means tests at $P=0.05$. Incidence of plants with galls among cultivars for each location and year were compared by nonparametric analysis as a result of nonnormal distributions from the subsamples using the Kruskal-Wallis test (Ott 1993). Regression analysis was used to investigate the effect of root galls on potato yield components with total yield (yield per plant), number of tubers per plant, and tuber weight analyzed separately as dependent variables, and gall index as the independent variable. Residual analysis was used to test normality and variance assumptions of the regression models. The association between gall index and actual number of galls per plant for each cultivar in 2012 was investigated using Spearman's rank correlation and regression analysis with galls per plant as the independent variable and gall index as the dependent variable. Actual number of galls per plant was not measured for the other years, as explained above. Statistical analyses were conducted using PROC GLM, PROC REG, PROC NPAR 1WAY, and PROC CORR in SAS (version 9.1; SAS Institute Inc., Cary, NC).

\section{Results}

Trials in 2007 and 2008. Powdery scab root galls were not observed on plants grown in the noninfested soil at Othello, WA in both years of the trial. Root galls were not recorded on potato plants grown at Warden, WA in 2007 but they were observed at that location in 2008 (Table 1). All plants of Umatilla Russet and Shepody had root galls, whereas only $11 \%$ of Summit Russet plants had root galls (Table 1). Plants of Summit Russet had significantly fewer $(P<$ 0.05) galls than Umatilla Russet or Shepody, whereas plants of Shepody had significantly more $(P<0.05)$ galls than either Summit Russet or Umatilla Russet in 2008. Mean gall index \pm the standard error of the mean (se) for Shepody, Umatilla Russet, and Summit Russet were $2.67 \pm 0.24,1.22 \pm 0.15$, and $0.11 \pm 0.11$, respectively.

Mean yield per plant was significantly greater $(P<0.05)$ for Shepody and Umatilla Russet than for Summit Russet at both locations in both years (Table 1). Mean yield per plant in 2008 was 2,078 to $2,263 \mathrm{~g}$ for Shepody and Umatilla Russet and 1,078 to $1,300 \mathrm{~g}$ for Summit Russet. Mean number of tubers per plant was significantly less $(P<0.05)$ for Summit Russet $(4.1)$ than the other two cultivars at Warden in 2008 (6.3 for Shepody and 10.2 for Umatilla Russet). Mean tuber weight was significantly greater $(P<0.05)$ for Shepody than for Umatilla Russet and Summit Russet, and did not significantly differ $(P>0.05)$ between Umatilla Russet and Summit Russet at both locations in 2008 (Table 1).

Yield ratios for mean yield per plant, mean number of tubers, and mean tuber weight were $\geq 0.99$ for Shepody and $>1.00$ for Umatilla Russet in 2008 (Table 1). Yield ratios for Summit Russet were $<1.00$ for mean yield per plant $(0.83)$ and number of tubers $(0.65)$ and $>1.00$ for tuber weight (1.30) in 2008.

Trials in 2010 through 2012. Powdery scab root galls were not observed on plants grown in the noninfested soil at Othello, WA in all 3 years of the trial. Root galls were observed on potato plants in the infested soil at Warden in 2010, 2011, and 2012 (Table 2). All plants of Umatilla Russet and Shepody had root galls, whereas, only

Table 1. Severity and incidence of root galls, yield components, and yield ratios for Summit Russet, Umatilla Russet, and Shepody planted in soils naturally infested with powdery scab (Spongospora subterranea) and in noninfested soils in separate locations in the Columbia Basin, WA in 2007 and $2008^{\mathrm{x}}$

\begin{tabular}{|c|c|c|c|c|c|}
\hline Year, disease/location, cultivar $(n)^{y}$ & Gall index & Gall incidence $(\%)$ & Yield/plant (g) & Number of tubers/plant & Mean tuber weight (g) \\
\hline \multicolumn{6}{|l|}{2007} \\
\hline \multicolumn{6}{|l|}{ Noninfested/Warden } \\
\hline Shepody (4) & 0 & 0 & $1,801 \mathrm{a}$ & $5.3 \mathrm{~b}$ & 340 a \\
\hline Umatilla Russet (4) & 0 & 0 & $1,784 \mathrm{a}$ & $10.8 \mathrm{a}$ & $166 \mathrm{c}$ \\
\hline Summit Russet (5) & 0 & 0 & $630 \mathrm{~b}$ & $3.3 \mathrm{c}$ & $193 \mathrm{~b}$ \\
\hline \multicolumn{6}{|l|}{ Noninfested/Othello } \\
\hline Shepody (5) & 0 & 0 & $2,098 \mathrm{a}$ & $6.4 \mathrm{~b}$ & $331 \mathrm{a}$ \\
\hline Umatilla Russet (6) & 0 & 0 & $1,995 \mathrm{a}$ & $10.9 \mathrm{a}$ & $183 \mathrm{~b}$ \\
\hline Summit Russet (5) & 0 & 0 & $1,061 \mathrm{~b}$ & $6.6 \mathrm{~b}$ & $161 \mathrm{~b}$ \\
\hline \multicolumn{6}{|l|}{2008} \\
\hline \multicolumn{6}{|l|}{ Infested/Warden } \\
\hline Shepody (6) & $2.67 \mathrm{a}$ & $100 \mathrm{a}$ & $2,098 \mathrm{a}$ & $6.3 \mathrm{~b}$ & 333 a \\
\hline Umatilla Russet (5) & $1.22 \mathrm{~b}$ & $100 \mathrm{a}$ & $2,263 \mathrm{a}$ & $10.2 \mathrm{a}$ & $221 \mathrm{~b}$ \\
\hline Summit Russet (4) & $0.11 \mathrm{c}$ & $11 \mathrm{~b}$ & $1,078 \mathrm{~b}$ & $4.1 \mathrm{c}$ & $261 \mathrm{~b}$ \\
\hline \multicolumn{6}{|l|}{ Noninfested/Othello } \\
\hline Shepody (6) & 0 & 0 & $2,078 \mathrm{a}$ & $6.2 \mathrm{~b}$ & $334 \mathrm{a}$ \\
\hline Umatilla Russet (6) & 0 & 0 & $2,080 \mathrm{a}$ & $9.5 \mathrm{a}$ & $219 \mathrm{~b}$ \\
\hline Summit Russet (6) & 0 & 0 & $1,300 \mathrm{~b}$ & $6.4 \mathrm{~b}$ & $203 \mathrm{~b}$ \\
\hline \multicolumn{6}{|l|}{ Yield ratio ${ }^{z}$} \\
\hline Shepody (6) & - & - & $1.01 \mathrm{ab}$ & $1.02 \mathrm{a}$ & $0.99 \mathrm{~b}$ \\
\hline Umatilla Russet (5) & - & - & $1.09 \mathrm{a}$ & $1.08 \mathrm{a}$ & $1.01 \mathrm{~b}$ \\
\hline Summit Russet (4) & - & - & $0.83 \mathrm{~b}$ & $0.65 \mathrm{~b}$ & $1.30 \mathrm{a}$ \\
\hline
\end{tabular}

x Values for each set of cultivars within a site and year with the same letter are not significantly different at $P=0.05$ using analysis of variance.

y Number of replicated plots (experimental units) $=n$, where each plot was a mean of 18 subsampled plants.

z Yield ratio was calculated for each yield component from each cultivar plot from infested soil divided by the mean of all plots of that cultivar from noninfested soil, where means were compared among cultivars using analysis of variance. 
41 to $53 \%$ of the Mesa Russet plants had root galls over the 3 years (Table 2). Severity of galls and incidence of root systems with galls were both significantly less $(P<0.05)$ for Mesa Russet than for Umatilla Russet in 2010, and were significantly less $(P<0.05)$ for Mesa Russet than for Umatilla Russet and Shepody in 2011 and 2012. Mean gall index \pm se for Shepody was $3.53 \pm 0.13$ in 2011 and $4.13 \pm 0.21$ in 2012. Mean gall index \pm se for the 3 years for Umatilla Russet was $1.83 \pm 0.14$ in 2010 to $2.87 \pm 0.0 .11$ in 2012 , and for Mesa Russet was $0.46 \pm 0.13$ in 2010 to $0.65 \pm 0.11$ in 2012 .

Mean yield per plant, mean number of tubers per plant, and mean tuber weight were significantly greater $(P<0.05)$ for Umatilla Russet than for Mesa Russet in infested and noninfested soil in 2010 (Table 2). Mean yield per plant did not significantly differ $(P>$ 0.05 ) among the three cultivars in infested and noninfested soil in 2011 and in infested soil at Warden in 2012 but was significantly greater $(P<0.05)$ for Umatilla Russet $(2,874 \mathrm{~g})$ than for Shepody $(1,899 \mathrm{~g})$ and Mesa Russet $(1,718 \mathrm{~g})$ in noninfested soil at Othello in 2012. Mean number of tubers were significantly greater $(P<$ 0.05 ) for Umatilla Russet (10.0 and 9.2 in infested and noninfested, respectively) and Mesa Russet (9.8 and 9.3 in infested and noninfested, respectively) than for Shepody (6.1 and 7.0 in infested and noninfested, respectively) in infested and noninfested soil in 2011, and was significantly greater $(P<0.05)$ for Umatilla Russet $(16.4$ and 22.6 in infested and noninfested, respectively) than Mesa
Russet and Shepody (range of means from 9.8 to 10.3) in infested and noninfested soil in 2012. Mean tuber weight did not differ significantly $(P>0.05)$ between Mesa Russet and Umatilla Russet in infested and noninfested soil in 2011 and between Mesa Russet and Shepody in infested and noninfested soil in 2012 (Table 2).

During 2010 to 2012, the yield ratio for total yield for Umatilla Russet was $<1$ in only 1 of 3 years $(0.82$ in 2012$)$ but was $\geq 1$ in 2 of 2 years (1.00 and 1.28 in 2010 and 2011, respectively) (Table 2). Total yield ratio was $>1$ for Shepody in 2 of 2 years (1.26 and 1.14 in 2011 and 2012, respectively), and was $>1$ for Mesa Russet in 2 of 3 years (1.25 and 1.45 in 2011 and 2012, respectively). Total yield ratio for Mesa Russet was 0.91 in 2010. The yield ratio for number of tubers was $<1$ in 2 of 3 years for Umatilla Russet $(0.82$ and 0.73 in 2010 and 2012, respectively), in 2 of 2 years for Shepody (0.87 and 0.89 in 2011 and 2012, respectively) but in only 1 of 3 years for Mesa Russet (0.92 in 2010). The ratio for mean tuber weight was notably $>1$ in 3 of 3 years for Umatilla Russet (1.23, 1.24, and 1.13 in 2010, 2011, and 2012, respectively), in 2 of 2 years for Shepody (1.44 and 1.30 in 2011 and 2012, respectively), and in 2 of 3 years for Mesa Russet (1.19 and 1.43 in 2011 and 2012, respectively). The ratio for mean tuber weight was 0.97 for Mesa Russet in 2010 .

Mean yield per plant, mean number of tubers, and mean tuber weight for Umatilla Russet and Shepody either did not significantly

Table 2. Severity and incidence of root galls, yield components, and yield ratios for Mesa Russet, Umatilla Russet, and Shepody planted in soils naturally infested with the powdery scab (Spongospora subterranea) and in noninfested soils in separate locations in the Columbia Basin, WA from 2010 to $2012^{\mathrm{w}}$

\begin{tabular}{|c|c|c|c|c|c|}
\hline Year, disease/location, cultivar ${ }^{\mathrm{x}}$ & Gall index & Gall incidence $(\%)$ & Yield/plant (g) & Number tubers/plant & Mean tuber weight (g) \\
\hline \multicolumn{6}{|l|}{$2010^{\mathrm{y}}$} \\
\hline \multicolumn{6}{|l|}{ Infested/Warden } \\
\hline Umatilla Russet & $1.83 \mathrm{a}$ & $100 \mathrm{a}$ & $2,810 \mathrm{a}$ & $11.9 \mathrm{a}$ & 235. a \\
\hline Mesa Russet & $0.46 \mathrm{~b}$ & $41 \mathrm{~b}$ & $2,194 \mathrm{~b}$ & $7.1 \mathrm{~b}$ & $311 . b$ \\
\hline \multicolumn{6}{|l|}{ Noninfested/Othello } \\
\hline Umatilla Russet & 0 & 0 & $2,803 \mathrm{a}$ & $14.7 \mathrm{a}$ & $191 \mathrm{a}$ \\
\hline Mesa Russet & 0 & 0 & $2,400 \mathrm{~b}$ & $7.7 \mathrm{~b}$ & $312 b$ \\
\hline \multicolumn{6}{|l|}{ Yield ratio $^{z}$} \\
\hline Umatilla Russet & $\ldots$ & $\ldots$ & $1.00 \mathrm{a}$ & $0.82 \mathrm{a}$ & $1.23 \mathrm{a}$ \\
\hline Mesa Russet & $\ldots$ & $\ldots$ & $0.91 \mathrm{a}$ & $0.92 \mathrm{a}$ & $0.97 \mathrm{~b}$ \\
\hline \multicolumn{6}{|l|}{2011} \\
\hline \multicolumn{6}{|l|}{ Infested/Warden } \\
\hline Shepody & $3.53 \mathrm{a}$ & $100 \mathrm{a}$ & $2,245 \mathrm{a}$ & $6.1 \mathrm{~b}$ & $362 \mathrm{a}$ \\
\hline Umatilla Russet & $2.23 \mathrm{~b}$ & $100 \mathrm{a}$ & $2,331 \mathrm{a}$ & $10.0 \mathrm{a}$ & $233 \mathrm{~b}$ \\
\hline Mesa Russet & $0.53 \mathrm{c}$ & $53 \mathrm{~b}$ & $2,633 \mathrm{a}$ & $9.8 \mathrm{a}$ & $265 \mathrm{~b}$ \\
\hline \multicolumn{6}{|l|}{ Noninfested/Othello } \\
\hline Shepody & 0 & 0 & $1,779 \mathrm{a}$ & $7.0 \mathrm{~b}$ & $254 \mathrm{a}$ \\
\hline Umatilla Russet & 0 & 0 & $1,742 \mathrm{a}$ & $9.2 \mathrm{a}$ & $190 \mathrm{~b}$ \\
\hline Mesa Russet & 0 & 0 & $2,101 \mathrm{a}$ & $9.3 \mathrm{a}$ & $226 a b$ \\
\hline \multicolumn{6}{|l|}{ Yield ratio ${ }^{z}$} \\
\hline Shepody & $\ldots$ & $\ldots$ & $1.26 \mathrm{a}$ & $0.87 \mathrm{a}$ & $1.44 \mathrm{a}$ \\
\hline Umatilla Russet & $\ldots$ & $\ldots$ & $1.28 \mathrm{a}$ & $1.07 \mathrm{a}$ & $1.24 \mathrm{a}$ \\
\hline Mesa Russet & $\ldots$ & $\ldots$ & $1.25 \mathrm{a}$ & $1.05 \mathrm{a}$ & $1.19 \mathrm{a}$ \\
\hline \multicolumn{6}{|l|}{2012} \\
\hline \multicolumn{6}{|l|}{ Infested/Warden } \\
\hline Shepody & $4.13 \mathrm{a}$ & $100 \mathrm{a}$ & $2,161 \mathrm{a}$ & $9.8 \mathrm{~b}$ & $220 \mathrm{a}$ \\
\hline Umatilla Russet & $2.87 \mathrm{~b}$ & $100 \mathrm{a}$ & $2,366 \mathrm{a}$ & $16.4 \mathrm{a}$ & $144 \mathrm{~b}$ \\
\hline Mesa Russet & $0.65 \mathrm{c}$ & $48 \mathrm{~b}$ & $2,498 \mathrm{a}$ & $10.2 \mathrm{~b}$ & $245 \mathrm{a}$ \\
\hline \multicolumn{6}{|l|}{ Noninfested/Othello } \\
\hline Shepody & 0 & 0 & $1,899 \mathrm{~b}$ & $11.0 \mathrm{~b}$ & $172 \mathrm{a}$ \\
\hline Umatilla Russet & 0 & 0 & $2,874 \mathrm{a}$ & $22.6 \mathrm{a}$ & $127 \mathrm{~b}$ \\
\hline Mesa Russet & 0 & 0 & $1,718 \mathrm{~b}$ & $10.3 \mathrm{~b}$ & $166 \mathrm{a}$ \\
\hline \multicolumn{6}{|l|}{ Yield ratio ${ }^{z}$} \\
\hline Shepody & $\ldots$ & $\ldots$ & $1.14 \mathrm{~b}$ & $0.89 \mathrm{ab}$ & $1.30 \mathrm{ab}$ \\
\hline Umatilla Russet & $\ldots$ & $\ldots$ & $0.82 \mathrm{c}$ & $0.73 \mathrm{~b}$ & $1.13 \mathrm{~b}$ \\
\hline Mesa Russet & $\ldots$ & $\ldots$ & $1.45 \mathrm{a}$ & $0.99 \mathrm{a}$ & $1.43 \mathrm{a}$ \\
\hline
\end{tabular}

${ }^{\text {w }}$ Values for each set of cultivars within a site and year with the same letter are not significantly different at $P=0.05$ using analysis of variance.

$\mathrm{x}$ Calculated from a mean of three subsampled plants each for gall index and yield per cultivar with 10 replications.

y Shepody was not grown in 2010.

z Yield ratio was calculated for each yield component from each cultivar plot from infested soil divided by the mean of all plots of that cultivar from noninfested soil, where means were compared among cultivars using analysis of variance. 
change $(P>0.05)$ or significantly increased $(P<0.05)$ as gall index increased in 2010 (Fig. 1), 2011 (Fig. 2), and 2012 (Fig. 3). Mean yield per plant for Shepody decreased as gall index increased in 2011 but only at the $11 \%(P=0.11)$ and not the 5\% $(P=0.05)$ significance levels of testing (Fig. 2). Mean tuber weight significantly increased as gall index increased for Umatilla Russet $(P=0.016)$ in 2010 and $2012(P=0.015)$. Mean number of tubers for Mesa
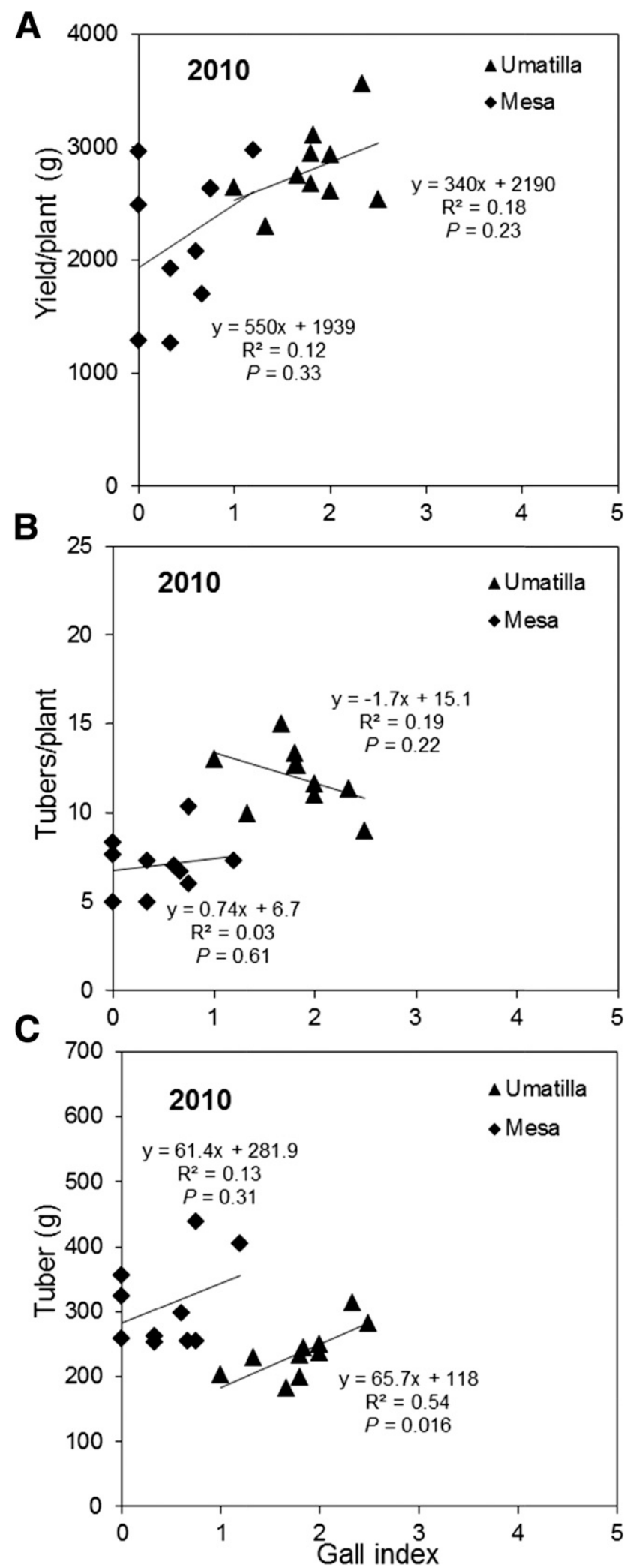

Fig. 1. Yield components for Umatilla Russet and Mesa Russet potato in relation to root gall index for galls caused by Spongospora subterranea at Warden, WA in 2010.
Russet significantly decreased $(P=0.02)$ as gall index increased in 2012 (Fig. 3) but not for any other yield component for Mesa Russet in the other 2 years (Figs. 1 and 2).

Number of galls per root system and gall index were significantly correlated in 2012 based on Spearman's rank correlation. Correlation
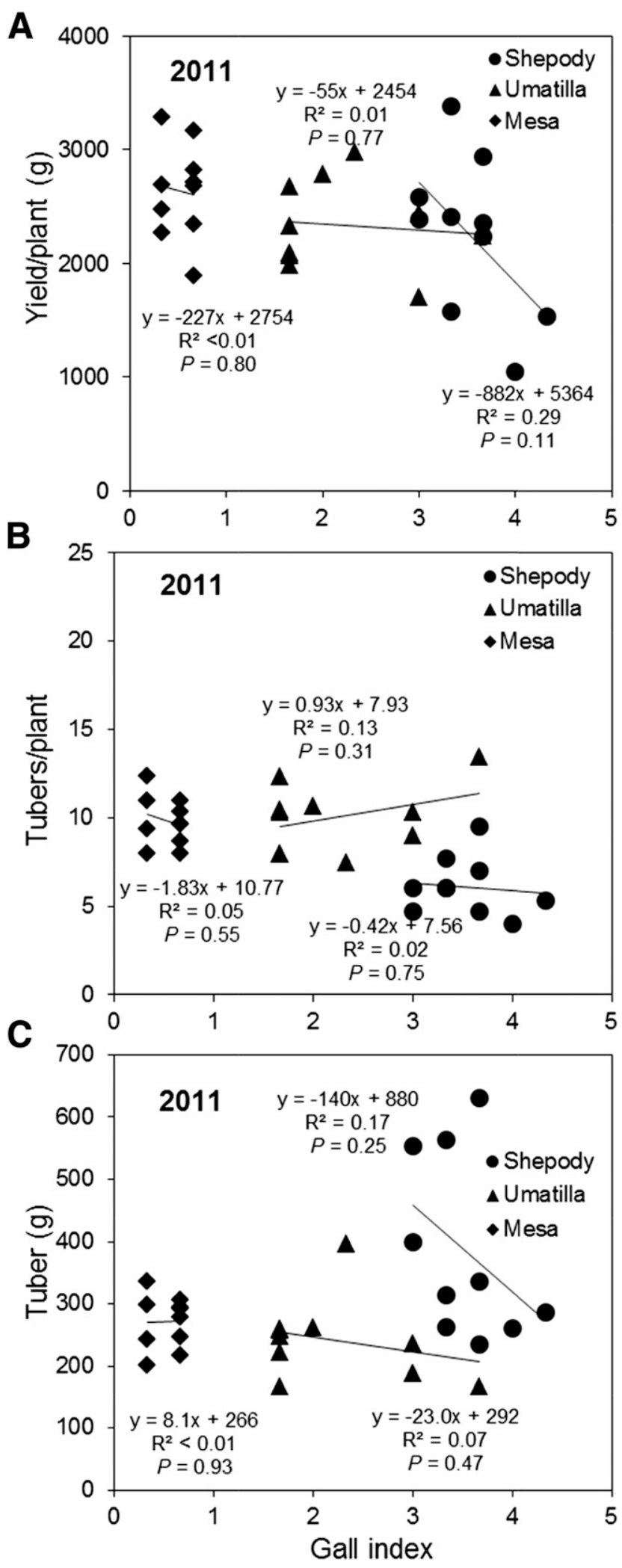

Fig. 2. Yield components for Shepody, Umatilla Russet, and Mesa Russet potato in relation to root gall index for galls caused by Spongospora subterranea at Warden, WA in 2011. 
coefficients were 0.96 for Umatilla Russet $(P<0.0001), 0.98$ for Shepody $(P<0.0001)$, and 0.70 for Mesa Russet $(P=0.025)$. Coefficients of determination were highly significant for Shepody (0.97) and Umatilla Russet (0.91) and moderate for Mesa Russet (0.45) (Fig. 4). Regression coefficients were significant for each of the three cultivars $(P<0.0001$ for Shepody and Umatilla Russet and $P<0.03$ for Mesa Russet) (Fig. 4), indicating that gall index increased as number of galls increased.
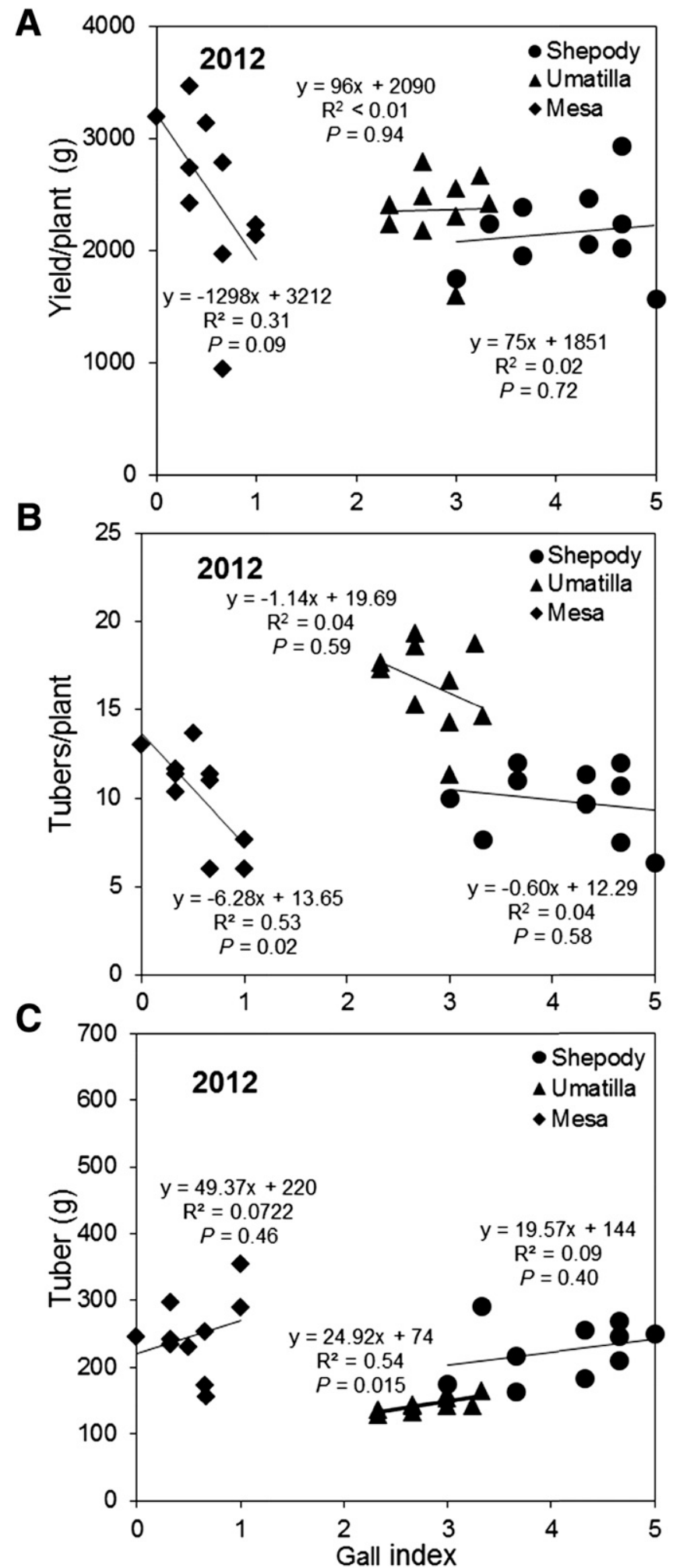

Fig. 3. Yield components for Shepody, Umatilla Russet, and Mesa Russet potato in relation to root gall index for galls caused by Spongospora subterranea at Warden, WA in 2012.

\section{Discussion}

Potato tuber yields for the three yield components of yield per plant, number of tubers per plant, and weight of tubers per plant were not negatively affected by powdery scab on roots of Umatilla Russet and Shepody, as indicated by the yield ratio measure for 3 of 4 years and by regression analyses calculated for 3 of 3 years. Regression lines with a nonsignificant slope or slopes that significantly increased with gall index also indicated that the number of root galls per plant did not reduce yield significantly. The yield ratios between infested and noninfested fields for mean yield per plant and mean numbers of tubers for Umatilla Russet in 2012 were the exception and, as this cultivar displayed, had low yield ratios. However, the regression slopes for those two variables for Umatilla Russet in 2012 did not decrease, indicating that yield was not affected by the number of powdery scab galls. The low yield ratios for Umatilla Russet that year were likely due to the cultivar producing a relatively high yield in the noninfested field, because significant differences were not recorded for total yield between the infested and noninfested soils. Shepody was more susceptible to root galling than Umatilla Russet but total yield was not affected significantly in either cultivar.

The significant increase in mean tuber weight with increasing root gall index for Umatilla Russet in 2010 and 2012 in this study was likely due to a decrease in number of tubers per plant, which increased mean tuber weight. This was supported by a yield ratio $<1.0$ for the number of tubers per plant in 2010 and 2012 but not in 2011 (Table 2). Consequently, tuber number per plant may be reduced with increasing number of powdery scab root galls per plant and, therefore, increase the mean tuber weight.

Yield ratios have been used previously to evaluate yield reductions caused by diseases (Dung et al. 2010; Johnson and Wilcoxson 1979). The yield ratios and regressions analyses in this study were both satisfactory methods of assessing the effect of powdery scab root galls on yield. The slopes of the yield component plots against number of galls or gall index likely gave a more precise indication of the effect of galling on yield than yield ratios. This is because the effect of disease severity on yield was considered using adjacent plants within the same plots and not compared between plots in different fields. However, yield ratios as determined in this study have validity in giving an estimate of the effect of disease on yield.

An action threshold greater than the number of galls encountered in this study on roots of Umatilla Russet and Shepody is needed before an economic loss can be expected at more severe levels of powdery scab, and to assess the economic viability of control tactics for powdery scab (Rowe and Powelson 2008). The mean gall index for Shepody was 4.13 in 2012, which represents 141 galls/plant. Currently, this represents the maximum number of galls encountered

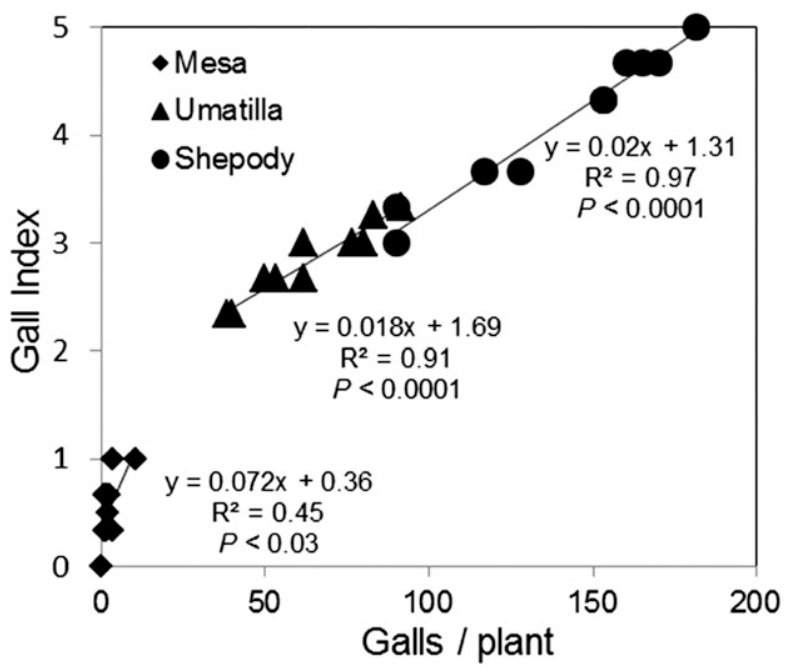

Fig. 4. Root gall index in relation to number of galls per plant for each of three potato cultivars at Warden, WA in 2012 
on potato roots in the Columbia Basin. A greater number of galls per plant may reduce potato yields. Consequently, the outcome of this study suggests that specific control tactics directed solely at preventing powdery scab galls on roots are not economically justified for powdery scab root galls in the Columbia Basin. However, $S$. subterranea and $C$. coccodes, the cause of potato black dot, may interact to produce more severe disease and plant damage (D. A. Johnson, unpublished data). Germplasm resistant to both S. subterranea root galling (Nitzan et al. 2008, 2010) and stem and root invasion by C. coccodes (Nitzan et al. 2009b) is available, and the development of cultivars resistant to both pathogens is desirable to reduce the harmful effects of interactions between the two pathogens on potato. Resistance to root galling could be important to prevent a buildup of soilborne inoculum for future growing seasons, even though there is no evidence of a direct effect of the disease on yield at levels of soilborne inoculum that have been detected in the Columbia Basin to date. On account of a potential synergistic interaction with $C$. coccodes, resistance to black dot development in roots should be sought. Furthermore, resistance to the tuber pustule phase of powdery scab would be a satisfactory tactic for controlling pustules on russeted tubers (Nitzan et al. 2010). Tuber resistance is probably a partial type of resistance in that a limited number of lesions can develop on tubers of russet skinned cultivars when disease pressure is severe.

The decrease in yield with increasing gall index observed on Mesa Russet in 2012 does not indicate that yield was affected by root galls on this resistant cultivar. The gall index for Mesa Russet ranged from 0 to 1 and represented a maximum of 15 galls/plant. One gall per plant resulted in a gall index of 1 . The narrow range for the dependent variable gall index was not sufficient to detect an effect on yield by regression analysis for Mesa Russet. A gall index was used in this study because counting individual galls on root systems was time consuming. Estimating the number of root galls and using the gall index was sufficiently accurate for the objectives of the study. The value of gall index, as expected, was directly correlated with the number of root galls observed per plant.

A reduction in potato yield due to powdery scab root galling was expected but not encountered in this study. The different reactions to root gall measured on potato in Colombia (Gilchrist et al. 2011) and Australia (Shah et al. 2012) versus this study may be associated with the cultivars, severity of root galls, environment, available soil moisture, and method of estimating the effect of the pathogen on yield. Severity of root galls on Shepody in this study was severe, with $>30 \%$ of the root area displaying galls. Potato roots with galls were demonstrated to have a reduced capacity to take up water in a study by Falloon et al. (2004), in which test plants were grown in soil infested with sporosori obtained by scraping powdery scab lesions from tubers produced in the field. An impediment of water uptake due to root galls might be overcome in the field with ample soil moisture provided by irrigation or rainfall. Pivot irrigation systems in the Columbia Basin of Washington State supply 50 to $76 \mathrm{~cm} / \mathrm{ha}$ for a growing season (Johnson et al. in press), which is a plentiful supply of water.

A comparison of yield from cultivars resistant and susceptible to root galling in naturally infested and noninfested field soil was used to measure the effect of powdery scab root galls on potato yield in this study. Yields of Shepody and Umatilla Russet, two commonly grown potato cultivars in the Columbia Basin, were not impaired by the levels of root galling caused by $S$. subterranea in this region. Evaluations were done in fields under conditions used for commercial potato production in the Columbia Basin of Washington State, not in a greenhouse or shadehouse. Consequently, control tactics directed solely at reducing powdery scab galls on roots are not economically justified at the levels of soilborne inoculum of $S$. subterranea encountered in the Columbia Basin fields used for this study.

\section{Acknowledgments}

We thank N. Nitzan, K. Tanaka, and D. Inglis for their reviews; and the senior editor and external reviewers for helpful suggestions. PPNS Number 0674, Department of Plant Pathology, College of Agricultural, Human, and Natural Resource Sciences, Agricultural Research Center, Hatch Project Number WNP0678, Washington State University, Pullman 99164-6430.

\section{Literature Cited}

Adams, M. J., Read, P. J., Lapwood, D. H., Cayley, G. R., and Hide, G. A. 1987 The effect of irrigation on powdery scab and other tuber diseases of potatoes. Ann. Appl. Biol. 110:287-294.

Alexopoulos, C. J. 1962. Introductory Mycology, 2nd ed. John Wiley and Sons, New York.

Bhattacharyya, S. K., and Raj, S. 1981. Studies on powdery scab of potatoes. II. Spore germination, artificial inoculation and histopathological studies. J. Indian Potato Assoc. 8:118-123.

Brown, C. R., Vandemark, G., Johnson, D., Cummings, T., Batchelor, D., Miller, J., and Olsen, C. 2007. Resistance to powdery scab in potato. Potato Progress 7:1. Washington State Potato Commission. Online publication. www.potatoes.com

Christ, B. J. 2001. Powdery scab. Pages 35-36 in: Compendium of Potato Diseases, 2nd ed. W. R. Stevenson, R. Loria, G. D. Franc, and D. P. Weingartner, eds. American Phytopathological Society, St. Paul, MN.

Christ, B. J., and Weidner, R. J. 1988. Incidence and severity of powdery scab on potatoes in Pennsylvania. Am. Potato J. 65:583-588.

Diriwachter, G., and Parbery, D. G. 1991. Infection of potato by Spongospora subterranea. Mycol. Res. 95:762-764.

Dung, J. K. S., Schroeder, B. K., and Johnson, D. A. 2010. Evaluation of Verticillium wilt resistance in Mentha arvensis and $M$. longifolia genotypes. Plant Dis. 94:1255-1260.

Falloon, R. E. 2008. Control of powdery scab of potato: Towards integrated disease management. Am. J. Potato Res. 85:253-260.

Falloon, R. E., Curtin, D., Lister, R. A., and Butler, R. C. 2004. The obligate soilborne pathogen Spongospora subterranea affects host (Solanum tuberosum) root function. Pages 30-31 in: Proc. 3rd Austral. Soilborne Disease Symp. K. M. Ophel Keller and B. H. Hall, eds. South Australian Research and Development Institute, Adelaide, Australia.

Foister, C. E., Wilson, A. R., and Boyd, A. E. W. 1952. Dry rot disease of the potato. I. Effect of commercial handling methods on the incidence of the disease. Ann. Appl. Biol. 39:29-37.

Gans, P. T., Carson, W. D., and Bishop, M. B. 1987. The susceptibility of potato cultivars to powdery scab caused by Spongospora subterranea (Wallr.) Lagerh. J. Natl. Inst. Agric. Bot. 17:337-343.

Gilchrist, E., Soler, J., Merz, U., and Reynaldi, S. 2011. Powdery scab effect on the potato Solanum tuberosum ssp. andigena growth and yield. Trop. Plant Pathol. 36:350-355.

Gudmestad, N. C. 2008. Potato health from sprouting to harvest. Pages 67-77 in: Potato Health Management, 2nd ed. D. A. Johnson, ed. American Phytopathological Society, St. Paul, MN.

Harrison, J. G., Searle, R. J., and Williams, N. A. 1997. Powdery scab disease of potato-A review. Plant Pathol. 46:1-25.

Houser, A. J., and Davidson, R. D. 2010. Development of a greenhouse assay to evaluate potato germplasm for susceptibility to powdery scab. Am. J. Potato Res. 87:285-298.

James, W. C. 1974. Assessment of plant diseases and losses. Annu. Rev. Phytopathol. 12:27-48.

Johnson, D. A., Cummings, T. F., and Fox, A. D. Accuracy of rain forecasts for use in scheduling late blight management tactics in the Columbia Basin of Washington and Oregon. Plant Dis. In press.

Johnson, D. A., and Miliczky, E. R. 1993. Distribution and development of black dot, Verticillium wilt, and powdery scab on Russet Burbank potatoes in Washington State. Plant Dis. 77:74-79.

Johnson, D. A., and Wilcoxson, R. D. 1979. Yield losses of fast and slow rusting barleys infected with Puccinia hordei. Plant Dis. Rep. 63:764-768.

Jones, R. A. C., and Harrison, B. D. 1969. The behavior of potato mop top virus in soil, and evidence for its transmission by Spongospora subterranea (Wallr.) Lagerh. Ann. Appl. Biol. 63:1-17.

Kole, A. P. 1954. A contribution to the knowledge of Spongospora subterranea (Wallr.) Legerh., the cause of powdery scab of potatoes. Tijdschr. Planten. 60:1-65.

Melhus, I. E., Rosenbaum, J., and Schultz, E. S. 1916. Spongospora subterranea and Phoma tuberosa on the Irish potato. J. Agric. Res. 7:213-271.

Merz, U. 2008. Powdery scab of potato - occurrence, life cycle and epidemiology Am. J. Potato Res. 85:241-246.

Merz, U., Martinez, V., and Schwarzel, R. 2004. The potential for the rapid screening of potato cultivars (Solanum tuberosum) for resistance to powdery scab (Spongospora subterranea) using a laboratory bioassay. Eur. J. Plant Pathol. 110:71-77.

Nitzan, N., Boydston, R., Batchelor, D., Crosslin, J., Hamlin, L., and Brown, C. 2009a. Hairy nightshade is an alternative host of Spongospora subterranea, the potato powdery scab pathogen. Am. J. Potato Res. 86:297-303.

Nitzan, N., Cummings, T. F., Johnson, D. A., Miller, J. S., Batchelor, D. L., Olsen, C., Quick, R. A., and Brown, C. R. 2008. Resistance to root galling caused by the powdery scab pathogen Spongospora subterranea in potato. Plant Dis. 92: 1643-1649.

Nitzan, N., Evans, M. A., Cummings, T. F., Johnson, D. A., Batchelor, D. L., Olsen, C., Haynes, K. G., and Brown, C. R. 2009b. Field resistance to potato stem colonization by the black dot pathogen, Colletotrichum coccodes. Plant Dis. 93:1116-1122.

Nitzan, N., Haynes, K. G., Miller, J. S., Johnson, D. A., Cummings, T. F., Batchelor, D. L., Olsen, C., and Brown, C. R. 2010. Genetic stability in 
potato germplasm for resistance to root galling caused by the pathogen Spongospora subterranea. Am. J. Potato Res. 87:497-501.

Ott, R. L. 1993. A nonparametric alternative: The Kruskal-Wallis test. Pages 792-806 in: An Introduction to Statistical Methods and Data Analysis. Duxbury Press, Belmont, CA.

Perla, V., Jayanty, S. S., Holm, D. G., and Davidson, R. D. 2014. Relationship between tuber storage proteins and tuber powdery scab resistance in potato. Am. J. Potato Res. 91:233-245.

Powelson, M. L., and Rowe, R. C. 2008. Managing diseases caused by seedborne and spoilborne fungi and fungus-like pathogens. Pages 183-195 in: Potato Health Management, 2nd ed. D. A. Johnson, ed. American Phytopathological Society, St. Paul, MN.

Qu, X., and Christ, B. J. 2006. The host range of Spongospora subterranea f. sp. subterranea in the United States. Am. J. Potato Res. 83:343-347.
Ramsey, G. B. 1918. Influence of moisture and temperature upon infection by Spongospora subterranea. Phytopathology 8:29-31.

Rowe, R. C., and Powelson, M. L. 2008. Potato health management: A holistic approach. Pages 1-5 in: Potato Health Management, 2nd ed. D. A. Johnson, ed. American Phytopathological Society, St. Paul, MN.

Schultz, E. S. 1952. Powdery scab, a precursor for the late blight infection of blight-immune potato tubers. (Abstr.) Phytopathology 42:343.

Shah, F. A., Falloon, R. E., Butler, R. C., and Lister, R. A. 2012. Low amounts of Spongospora subterranea sporosorus inoculum cause severe powdery scab, root galling and reduced water use in potato (Solanum tuberosum). Austral. Plant Pathol. 41:219-228.

Wade, G. C. 1949. An unusual potato rot. J. Aust. Inst. Agric. Sci. 15:42-43.

Walker, J. C. 1950. Powdery scab of potato. Pages 164-167 in: Plant Pathology. McGraw-Hill, New York. 